\title{
Influence of endophyte-infected fescue on serum concentrations of leptin in female ruminants
}

\author{
J.M. BURKE ${ }^{1}$, D.H. KEISLER ${ }^{2}$ and R.W. RORIE ${ }^{3}$ \\ ${ }^{I}$ U.S. Department of Agriculture, Agricultural Research Service, Booneville, AR 72927, USA \\ ${ }^{2}$ Department of Animal Science, University of Missouri, Columbia, MO 65211, USA \\ ${ }^{3}$ Department of Animal Science, University of Arkansas, Fayetteville, AR 72701, USA
}

jmburke@spa.ars.usda.gov

\begin{abstract}
The objective was to determine whether leptin played a role in abnormal reproductive function in ruminant females fed endophyte-infected (EI) tall fescue. Cow-calf pairs grazed endophyte-free (EF) or EI tall fescue starting in mid-April (early spring) for 2 years and yearling ewes were fed an EF or EI fescue seed diet for up to 37 days to examine signs of fescue toxicosis and measure serum concentrations of leptin. Signs of fescue toxicosis were present in EI fed cows and ewes. Serum concentrations of leptin were reduced in cows grazing EI compared with EF fescue from mid- to late May in the first year grazing trial, but not the second and were similar between EF and EI-fed ewes. Leptin concentrations also were reduced in cows which grazed EI fescue in the first year and lost a pregnancy before 126 days of gestation compared with cows that maintained. The mechanisms of increased embryonic losses in cows experiencing fescue toxicosis is not known, but may be associated with reduced nutritional status of the pregnant animal.
\end{abstract}

Keywords: cows, ewes, fescue, leptin, reproduction

\section{Introduction}

Although tall fescue is an integral part of forage grazing systems in the southeastern U.S., pregnancy and calving rates suffer (Brown et al. 1997; 1992; Gay et al. 1988) because of ergot alkaloids produced by the fungus that grows within the plant consumed by livestock. Problems with reproduction are coupled with reductions in feed intake, weight gains, and body condition scores, as well as changes in lipid metabolism, inability to regulate body temperature, and decreased circulating concentrations of prolactin (Oliver 1997; Porter \& Thompson 1992). Mechanisms by which ergot alkaloids convey a negative effect to the reproductive system are not clear. Changes in lipid metabolism have been observed as decreased concentrations of total cholesterol in the blood (Oliver 1997; Stuedemann et al. 1985), decreased percentage of unsaturated fatty acids in tissues, and increased saturated fatty acids in cattle grazing infected fescue compared with those grazing endophyte-free tall fescue (Townsend et al. 1991), all of which may impact reproductive hormones.

Leptin plays a role in nutrition and reproduction. Leptin is correlated to the amount of adipose stores in sheep and cattle (Chilliard et al. 1998; Blache et al. 2000) and may facilitate signals to areas of the brain that regulate energy metabolism, feed intake (Houseknecht et al. 1998; Casanueva \& Dieguez 1999) and may play a role in maintenance of reproduction in ruminants (Spicer \& Francisco 1998; Amstalden et al. 2000; Bonnet et al. 2002). Acute feed restriction was associated with a decrease in plasma concentrations of leptin in pre-pubertal heifers (Amstalden et al. 2000). The objective of these studies was to determine whether consumption of endophyte-infected (EI) tall fescue was associated with decreased serum concentrations of leptin in ewes and cows.

\section{Methods}

All experimental procedures were reviewed and accepted by the Agricultural Research Service Animal Care and Use Committee in accordance with the NIH guide for the Care and Use of Laboratory Animals.

\section{Cows grazing endophyte-free or infected tall fescue}

Mature cows ( 1 to 53 days post-partum) with calves were randomly assigned to graze endophyte-free tall fescue $(\mathrm{EF} ; \mathrm{n}=$ $20 ; 16$ ha paddock) or EI ( $\mathrm{n}=30 ; 24$ ha paddock) tall fescue starting in mid-April (Day 0 = first day of grazing; early spring). Breeds were Angus, Hereford, or Angus $\times$ Hereford crossbred. Pastures were fertilised based on soil recommendations and grazed continuously year round. Serum was collected for prolactin analysis on Day 52 and weekly from Days 7 through 108 for leptin determination. Pregnancy status of cows was determined between 30 and 126 days post-breeding.

The following year, mature cow-calf pairs between 19 and 50 days post-partum were blocked by body weight and randomly assigned to graze $\mathrm{EF}(\mathrm{n}=12 ; 16$ ha paddock) or $\mathrm{EI}(\mathrm{n}=16 ; 24$ ha paddock) fescue in mid-April (Day $0=$ first day of grazing). Breeds were similar to previous year. Blood was collected for determination of serum concentration of leptin on Days 40, 47, and 54 of grazing. Pasture conditions and management were similar to the previous year. Serum concentrations of leptin were analysed using a heterologous leptin RIA (Delavaud et al. 2000).

Ewes fed an endophyte-free or infected tall fescue seed diet Peri-pubertal yearling Hampshire (first year) or Dorper crossbred (second year) ewes were randomly assigned to an EF or EI fescue seed diet ( $n=6$ per diet) for up to 37 days in autumn. The EF diet consisted of $50 \%$ ground EF fescue seed ( $0 \mu \mathrm{g} / \mathrm{g}$ of ergovaline), $43.4 \%$ chopped bermudagrass hay, $5 \%$ molasses, $1.1 \%$ soybean meal, $0.5 \%$ limestone on a DM basis. The EI diet consisted of $50 \%$ ground EI fescue seed ( $2.5 \mu \mathrm{g} / \mathrm{g}$ of ergovaline), $40.2 \%$ chopped bermudagrass hay, $5 \%$ molasses, $4.3 \%$ soybean meal, $0.5 \%$ limestone on a DM basis. Crude protein (\% DM) was $16.8 \%$ for the EF fescue seed and $14.5 \%$ for the EI fescue seed. Ergovaline content of fescue seed was determined by high-performance liquid chromatography (Rottinghaus et al. 1991). The EI diet provided approximately $1875 \mu \mathrm{g}$ ergovaline/day. Feed offered to the ewes fed the EF diet was reduced to the average intake of the ewes fed the EI diet from the previous day so that intake between diets was similar. Body weight was determined on Days 0 and 37 (Day $0=$ first day of feeding seed diet).

\section{Statistical analyses}

Data were analysed by mixed models procedure of the Statistical Analysis System (1996). The mathematical model that was used to analyse serum concentrations of leptin included effects of diet for ewes and effects of diet, breed, and the interaction for cows. 
Figure 1 Least squares means and standard errors of serum concentrations of leptin for cows grazing endophyte-free (EF; $n=17$; open circles) or infected (El; $\mathrm{n}=27$; closed squares) tall fescue. Grazing treatments began in mid-April (spring). Single $(\mathrm{P}<0.05)$ and double $(P<0.01)$ asterisk represents treatment differences.

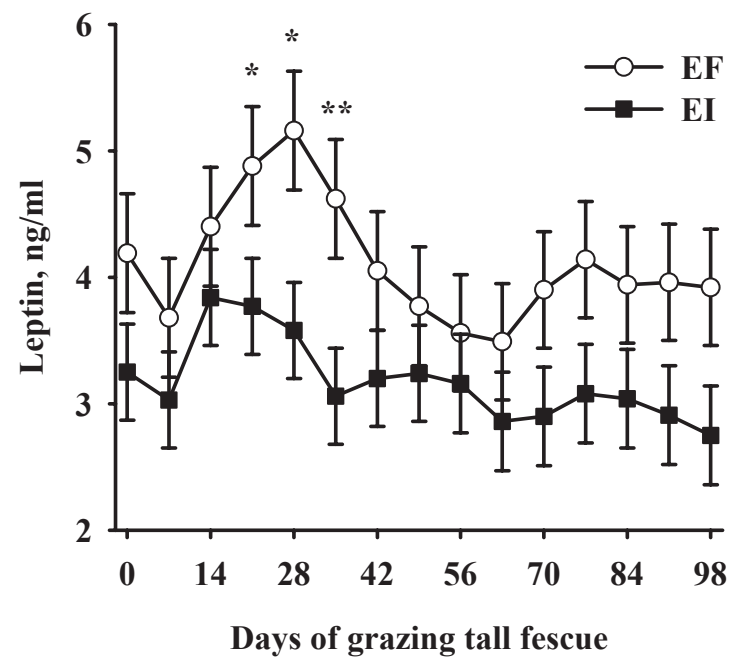

Because BCS was different between cows fed the EF and EI diets in the first year, it was used as a covariate. Heterogeneity of regression was used to detect an interaction between forage treatment and pregnancy status (maintenance or loss of pregnancy between 30 and 126 days of gestation).

\section{Results and Discussion}

Signs of fescue toxicosis existed in ruminant females consuming EI tall fescue forage or seed in all of these studies, including decreased serum concentrations of prolactin and body weight and condition as reported earlier (Burke et al. 2001a, 2006; Burke \& Rorie 2002). Pregnancy rate in cows 60 days post-breeding was similar between forage groups (first year: EF, 86.7 and EI, 81.2 $\pm 9 \%$; second year: EF, 83.3 and EI, $88.1 \pm 8 \%$; $>>0.10$ ). Serum concentrations of leptin were lower in cows grazing EI fescue from mid- to late May (spring) in the first year (treatment $\times$ time, $\mathrm{P}<0.03$; Fig. 1) and were lower in cows fed the EI diets that lost a pregnancy before 126 days of gestation (EF, 5.5 and EI, $17.6 \pm$ $8 \% ; \mathrm{P}>0.10)$ compared with those that maintained a pregnancy (treatment $\times$ pregnancy status, $\mathrm{P}<0.001$ ). Leptin concentrations continued to decline over time in EF and EI-grazed cows that lost a pregnancy in the first year. Similarly, in women who spontaneously miscarried, decreased circulating leptin was observed compared with those women who maintained the pregnancy (Laird et al. 2000; Lage et al. 1999; Unkila-Kallio et al. 2001). Body condition, but not body weight, was lower in EIgrazed cows as reported previously (Burke et al. 2001a). Although body condition was accounted for in the statistical model, there may have been other physiological differences between EF and EI exposed cows associated with a greater susceptibility to reproductive dysfunction. Changes in reproductive function that occurred during May that coincided with decreased leptin may have led to more numerical losses in pregnancy. The following year, serum concentrations of leptin were not different, but numerically higher, for cows grazing EI fescue compared with those grazing EF fescue for three consecutive weekly samples early in the grazing period $(\mathrm{P}>0.10)$. Pregnancy losses in early to mid-pregnancy were similar between forage treatments in the second year and perhaps environmental conditions were less conducive for fescue toxicosis.

Serum concentrations of leptin were not different between ewes fed EF or EI tall fescue seed after 26 days (Year 1: EF, 1.6; EI, $1.7 \pm 0.3 \mathrm{ng} / \mathrm{ml}$ ) or 30 days (Year 2: EF, $2.0 ; \mathrm{EI}, 1.7 \pm 0.3 \mathrm{ng} / \mathrm{ml}$ ), yet serum concentrations of prolactin were markedly reduced in ewes fed EI fescue seed diets the first $(0.4<66.6 \pm 7.9 \mathrm{ng} / \mathrm{ml}$; $\mathrm{P}<0.001)$ and second year $(\mathrm{P}<0.007)$. Sheep appear to be less susceptible to fescue toxicosis (Porter \& Thompson 1992) and were in better condition.

Serum concentrations of progesterone and small follicle (1 to $2 \mathrm{~mm}$ in diameter) development was reduced in ewes fed EI seed (Burke et al. 2006). Similarly, size of the largest follicle observed during the early luteal phase and numbers of mediumsized (6 - $9 \mathrm{~mm}$ ) follicles were decreased in EI fed cows in 2000 (Burke \& Rorie 2002) and serum progesterone was decreased in heifers (Burke et al. 2001b). Leptin has an inhibitory effect on steroidogenesis (Spicer \& Francisco 1998; Zachow \& Magoffin 1997) and attenuates FSH-induced follicle growth in mice (Kikuchi et al. 2001). In cycling ruminants, changes in follicle and luteal function and development associated with fescue toxins are not likely to be mediated by leptin because concentrations of this peptide were similar between EF and EI fed ruminants.

In summary, a decrease in peripheral concentrations of leptin was observed in cows grazing

EI fescue the first year, but not the next, and was not observed in ewes. Changes in ovarian development and function during the cycle in ruminants consuming EI tall fescue do not appear to be moderated by leptin. Decreased leptin during early pregnancy in cattle that grazed EI fescue may have led to or been associated with increased pregnancy losses. A clearer understanding of events that occur during early pregnancy that lead to embryo loss is needed to improve management strategies for cattle grazing EI tall fescue.

\section{ACKNOWLEDGEMENTS}

The authors are grateful to J. Cherry, W. Jackson, G. Robson, T. Preston, D. Jones for technical assistance and animal handling. Mention of trade names or commercial products in this manuscript is solely for the purpose of providing specific information and does not imply recommendation or endorsement by the U.S. Department of Agriculture.

\section{REFERENCES}

Amstalden, M.; Garcia, M.R.; Williams, S.W.; Stanko, R.L.; Nizielski, S.E.; Morrison, C.D.; Keisler, D.H.; Williams, G.L. 2000. Leptin gene expression, circulating leptin, and luteinizing hormone pulsatility are acutely responsive to short-term fasting in prepubertal heifers: relationships to circulating insulin and insulin-like growth factor I. Biology of Reproduction 63: 127-133.

Blache, D.; Tellam, R.L.; Chagas, L.M.; Blackberry, M.A.; Vercoe, P.E.; Martin, G.B. 2000. Level of nutrition affects leptin concentrations in plasma and cerbrospinal fluid in sheep. Journal of Endocrinology 165: 625-637.

Bonnet, M.; Gourdou, I.; Leroux, C.; Chilliard, Y.; Djiane, J. 2002. Leptin expression in the ovine mammary gland: Putative sequential involvement of adipose, epithelial, and myoepithelial cells during pregnancy and lactation. Journal of Animal Science 80: 723-728. 
Brown, M.A.; Tharel, L.M.; Brown, A.H. Jr; Miesner, J.R.; Jackson, W.G. 1992. Reproductive performance of Angus and Brahman cows grazing common bermudagrass or endophyteinfected tall fescue. Professional Animal Scientist 8: 58-65.

Brown, M.A.; Brown, A.H. Jr; Jackson, W.G.; Miesner, J.R. 1997. Genotype $x$ environment interactions in Angus, Brahman, and reciprocal cross cows and their calves grazing common bermudagrass and endophyte-infected tall fescue pastures. Journal of Animal Science 75: 920-925.

Burke, J.M.; Rorie, R.W. 2002. Changes in ovarian function in mature beef cows grazing endophyte infected tall fescue. Theriogenology 57: 1733-1742.

Burke, J.M.; Rorie, R.W.; Piper, E.L.; Jackson, W.G. 2001a. Reproductive responses to grazing endophyte-infected tall fescue by postpartum beef cows. Theriogenology 56: 357-369.

Burke, J.M.; Spiers, D.E.; Kojima, F.N.; Perry, G.A.; Salfen, B.E.; Wood, S.E.; Patterson, D.J.; Smith, M.F.; Lucy, M.C.; Jackson, W.G.; Piper, E.L. 2001b. Interaction of endophyteinfected fescue and heat stress on ovarian function in the beef heifer. Biology of Reproduction 65: 260-268.

Burke, J.M.; Bishop, C.; Stormshak F. 2006. Reproductive characteristics of endophyte-infected or novel tall fescue fed ewes. Livestock Science 104: 103-111.

Casanueva, F.F.; Dieguez, C. 1999. Neuroendocrine regulation and actions of leptin. Front Neuroendocrinology 20: 317-363.

Chilliard Y, Bocquier F, Doreau M. 1998.Digestive and metabolic adaptations of ruminants to undernutrition, and consequences on reproduction. Reproduction, Nutrition, Development 38: 131-152.

Delavaud, C.; Bocquier, F.; Chilliard, Y.; Keisler, D.H.; Gertler, A.; Kann, G. 2000. Plasma leptin determination in ruminants: effect of nutritional status and body fatness on plasma leptin concentration assessed by a specific RIA in sheep. Journal of Endocrinology 165: 519-526.

Gay, N.; Boling, J.A.; Dew, R.; Miksch, D.E. 1988. Effects of endophyte-infected tall fescue on beef cow-calf performance. Applied Agricultural Research 3: 182-186.

Houseknecht, K.L.; Baile, C.A.; Matteri, R.L.; Spurlock, M.E. 1998. The biology of leptin: A review. Journal of Animal Science 76: 1405-1420.

Kikuchi, N.; Andoh, K.; Abe, Y.; Yamada, K.; Mizunuma, H.; Ibuki, Y. 2001. Inhibitory action of leptin on early follicular growth differs in immature and adult female mice. Biology of Reproduction 65: 66-71.

Laird, S.M.; Quinton, N.D.; Anstie, B.; Li, T.C.; Blakemore,
A.I. 2001. Leptin and leptin-binding activity in women with recurrent miscarriage: correlation with pregnancy outcome. Human Reproduction 16: 2008-2013.

Lage, M.; Garcia-Mayor, R.V.; Tome, M.A.; Cordido, F.; ValleInclan, F.; Considine, R.V.; Caro, J.F.; Dieguez, C.; Casanueva, F.F. 1999. Serum leptin levels in women throughout pregnancy and the postpartum period and in women suffering spontaneous abortion. Clinical Endocrinology (Oxford) 50: 211-216.

Oliver, J.W. 1997. Physiological manifestations of endophyte toxicosis in ruminant and laboratory species. pp. 311-346. In: Proceedings of the 3rd International Symposium on Acremonium/Grass Interactions, Athens, GA.

Porter, J.K.; Thompson, F.N. Jr. 1992. Effects of fescue toxicosis on reproduction in livestock. Journal of Animal Science 70: 1594-1603.

Rottinghaus, G.E.; Garner, G.B.; Cornell, C.N.; Ellis, J.L. 1991. HPLC method for quantitating ergovaline in endophyteinfested tall fescue: seasonal variation of ergovaline levels in stems with leaf sheaths, leaf blades, and seed heads. Journal of Agricultural and Food Chemistry 39: 112-115.

SAS/STAT ${ }^{\circledR}$ Software: Changes and Enhancements through Release 6.11. 1996. SAS Inst, Inc, Cary, NC.

Spicer, L.J.; Francisco, C.C. 1998. Adipose obese gene product, leptin, inhibits bovine ovarian thecal cell steroidogenesis. Biology of Reproduction 58: 207-212.

Stuedemann, J.A.; Rumsey, T.S.; Bond, J.; Wilkinson, S.R.; Bush, L.P.; Williams, D.J.; Caudle, A.B. 1985. Association of blood cholesterol with occurrence of fat necrosis in cows and tall fescue summer toxicosis in steers. American Journal of Veterinary Research 46: 1990-1995.

Townsend, W.E.; Snook. M.E.; Stuedemann, J.A.; Wilson, R.L. 1991. Effect of level of endophyte infection, nitrogen fertilization rate, grazing period, and paddock exchange on some chemical properties of four bovine tissues. Journal of Animal Science 69: 2871-2882.

Unkila-Kallio, L.; Andersson, S.; Koistinen, H.A.; Karonen, S.L.; Ylikorkala, O.; Tiitinen, A. 2001. Leptin during assisted reproductive cycles: the effect of ovarian stimulation and of very early pregnancy. Human Reproduction 16: 657-662.

Zachow, R.J.; Magoffin, D.A. 1997. Direct intraovarian effects of leptin: impairment of the synergistic action of insulin-like growth factor-I on follicle-stimulating hormone-dependent estradiol-17 $\beta$ production by rat ovarian granulosa cells. Endocrinology 138: 847-850. 